\title{
AN ANALYSIS OF ADHERENCE TO FILLING OUT SURGICAL SAFETY CHECKLIST FOR AN IMPROVED PATIENT SAFETY AT NUR ROHMAH HOSPITAL, GUNUNGKIDUL, YOGYAKARTA
}

\author{
Muhammad Arif Budi Prakoso, Elsye Maria Rosa \\ Masters Program in Hospital Management, Universitas Muhammadiyah Yogyakarta
}

\begin{abstract}
Background: Surgical safety checklist aims to decrease errors and adverse events, and to increase teamwork and communication in surgery. Surgical safety checklist is expected to decrease complication and death due to surgery. This study aimed to assess adherence to filling out surgical safety checklist among surgical related medical professionals at Nur Rohmah Hospital, Gunungkidul, Yogyakarta.

Subjects and Method: This was a semi-qualitative case study conducted at Nur Rohmah Hospital, Gunungkidul, Yogyakarta. A sample of surgeons, anesthesiologists, surgery nurses, and anesthesia nurses, was selected for this study. The data related to adherence to filling out surgical safety checklist was measured by indepth interview, checklist, observation, and document review.

Results: Of the 25 surgeries performed, $100 \%$ of the sign in phase surgical safety checklist was filled out, and $83.42 \%$ of the time out phase surgical safety check list was filled out. Only about $24 \%$ of the surgeons introduced themselves and explained their roles. About $60 \%$ of the surgeons provided prophylactic antibiotics 60 minutes before surgery.

Conclusion: Adherence to phase surgical safety was good at Nur Rohmah Hospital, Yogyakarta. However, there remains the need for supervision, development of standard operating procedure, socialization, and training, to improve adherence to surgical safety checklist for an improved patient safety.
\end{abstract}

Keywords: surgical safety checklist, sign in, time out

\section{Correspondence:}

Muhammad Arif Budi Prakoso. Masters Program in Hospital Management, Universitas Muhammadiyah Yogyakarta, Jl. Lingkar Selatan, Tamantirto, Kasihan, Bantul, Yogyakarta. Email: arifbudipra@gmail.com. Mobile: 0821384692. 